\title{
Enriching table eggs with omega-3 fatty acids by using ground flaxseed or a combination of flax cake and flaxseed oil in the diet of laying hens
}

\author{
Jovo Perić*, and Milanka Drinić \\ Faculty of Agriculture, University of Banja Luka, Banja Luka, Bosnia and Herzegovina
}

PERIĆ, J., M. DRINIĆ: Enriching table eggs with omega-3 fatty acids by using ground flaxseed or a combination of flax cake and flaxseed oil in the diet of laying hens. Vet. arhiv 91, 399-409, 2021.

\section{ABSTRACT}

The purpose of the study was to investigate the potential of feeding laying hens with ground flax, a combination of flax cake and flax oil in the production of eggs enriched with omega- 3 fatty acids. The experiment was set up using 192 laying hens divided into 4 groups: the control group; a group fed with flaxseed cake (10\%) + flaxseed oil (2\%); a group fed with 5\% ground flax, and a group fed with 10\% ground flax. Each group had 8 cages housing 6 laying hens, that is, a total of 48 laying hens per group. The Haugh unit values, fat content, Thiobarbituric acid reactive substances (TBARS) values, yolk color parameters and yolk fat content were measured at the end of 5th and 10th weeks of the trial. The results of this study showed that omega- 3 enriched dietary treatments had an impact on the results obtained for the amount of total fat in the yolk, and the results of the TBARS test. The results presented show that the average amounts of alpha linoleic (ALA) and docosahexaenoic (DHA) fatty acids in egg yolk were influenced by the nutritional treatments, i.e. the laying hens that were fed with mixtures enriched with $5 \%$ and $10 \%$ ground flaxseed, as well as $10 \%$ flaxseed cake $+2 \%$ flaxseed oil, had significantly $(\mathrm{P}<0.05)$ higher amounts of ALA and DHA in their egg yolk compared to the laying hens in the control group.

Key words: laying hens; diet; flax; flax cake; flax oil; enriched eggs

\section{Introduction}

Eggs are an excellent source of nutrients for humans. Enrichment of table eggs with omega-3 fatty acids may be achieved by feeding laying hens with nutrients of animal and vegetable origin. In this way, eggs become a functional foodstuff. Functional foods may be defined as foods or food ingredients that may enhance health through their provision of a physiological benefit beyond traditional nutrients (SALEH, 2013). PUFAs had positive effects on human health (POLAWSKA et al., 2013). JUTURU (2008) stateed that omega-3 fatty acids are essential nutrients for the growth and development of the human body and play a role in reducing blood pressure, inflammation, and in reducing the risk of sudden death due to cardiac arrest. Nutritionally important omega-3 fatty acids are alpha-linoleic (ALA, C18:3 n-3), eicosapentaenoic (EPA, C20:5 n-3) and docosahexaenoic (DHA, C22:6 n-3) (COOREY et al., 2014). Vegetable oils are a major source of ALA. The use of a mixture with the addition of rapeseed (3\%), flax (1.5\%) and fish oil (1.5\%) in the diet of fattening chickens was an effective way of modifying the fatty acid composition of chicken meat (ČENGIĆ-DŽOMBA et al., 2014). Adding

\footnotetext{
*Corresponding author:

Jovo Perić, Master Agricultural Engineer, Faculty of Agriculture, University of Banja Luka, Bulevar vojvode Petra Bojovića 1A, Bosnia and Herzegovina, Phone: +387 65366 740, E-mail: jovo.peric@yahoo.com
} 
flaxseed oil + selenium to feed in growing rabbits had a beneficial effect on the composition of the meat lipid fraction, by increasing the concentration of unsaturated fatty acids and decreasing the concentration of saturated fatty acids, which is also a strategy to ensure an adequate supply of n-3 PUFA for the greater population (SALEH et al., 2013). The use of omega-3 fatty acids enabled the production of omega-3 enriched eggs with a more desirable omega-6/omega-3 ratio compared to conventionally produced eggs (ŠEFER et al., 2011).

The type and amount of omega-3 sources (fish oil, flax, chia) affected the content of omega-3 in the yolk. Chia could be incorporated into feed up to $30 \%$ resulting in high levels of omega-3 fatty acids in the yolk, without significantly affecting the sensory quality of the egg. Although the price of flax is lower compared to chia and fish oil, incorporating $30 \%$ of flax into feed was not recommended because it significantly reduced the sensory quality of eggs (COOREY et al., 2014).

The purpose of the experiment was to investigate the effect of low (5\%) and moderate (10\%) levels of ground flaxseed in the diet of the laying hens, and the impact of flaxseed processing products (flax cake $10 \%+$ flaxseed oil $2 \%$ ) on the total fat content in eggs, omega-3 PUFA fatty acid levels, Haugh units results and lipid oxidation, as well as yolk color parameters.

\section{Material and methods}

Laying hens, diet and experiment design. The experiment was set up on a commercial farm for table egg production in Bosnia and Herzegovina (coordinates $44^{\circ} 56^{\prime} 40^{\prime \prime} \mathrm{N}, 018^{\circ} 38^{\prime} 33^{\prime}$ " E) and all procedures used in this study were in accordance with the national standards (Protection Law and Animal Welfare, 25/2009 and 9/2018).

Laying hens of a hybrid Lohmann BrownClassic light line were used in the experiment, and were divided into four experimental groups: the control group, a group fed with flax cake at a concentration of $10 \%+$ flaxseed oil added to feed at a concentration of $2 \%$, a group fed with $5 \%$ ground flaxseed, and a group fed with $10 \%$ ground flaxseed. The experiment began at the 27 th week of the laying hens' age. Each group had 8 cages or 8 repetitions. There were 6 laying hens in each cage.

The chemical composition of flaxseed, flaxseed cake and flax oil is presented in Table 1.

The composition of the feed used for the diet of the laying hens is presented in Table 2.

Table 3 presents the results of the analysis of the feed of laying hens on the total fat content and fatty acid composition.

Testing the quality of eggs. The fat content of the eggs was determined by the FOLCH method (1957) at the end of $5^{\text {th }}$ and $10^{\text {th }}$ weeks from the start of the experiment, on a sample of 10 eggs per cage.

Fatty acid composition was determined using gas chromatography at the end of the $5^{\text {th }}$ and $10^{\text {th }}$ weeks from the start of the experiment. A gas chromatograph (Perkin-elmer Varian 1400), coupled to a charged column $(1=3 \mathrm{~m}, \mathrm{~d}=3.0$ $\mathrm{mm}$; stationary phase - GP 10\% SPTM-2330) and a flame ionization detector was used to determine the fatty acid composition. The temperature in the injection block and the detector was $250{ }^{\circ} \mathrm{C}$. In the gas chromatographic analysis, $\mathrm{N}_{2}$ at a flow rate of $20 \mathrm{ml} / \mathrm{min}$ was used as the carrier gas. The sample volume was $2.0 \mu \mathrm{L}$. Methyl esters of fatty acids, expressed in $\%$, were determined in comparison with the retention times of standard substances (Sigma-Aldrich Chemical, USA).

The TBARs test was determined by a spectrophotometric method (BOSTOGLOU et al., 1994; MANDIĆ, 2007) based on the measurement of the absorption of a complex colored compound formed by the reaction of malondialdehyde (MDA) and 2 thiobarbituric acid (TBA) molecules. The Haugh units were determined at the end of the $5^{\text {th }}$ and $10^{\text {th }}$ weeks of the trial, using the formula:

$$
\text { H.V. }=100 * \log \left(\mathrm{h}-1.7 * \mathrm{G}^{0.37}+7.6\right)
$$

$\mathrm{h}$ - height of the white $(\mathrm{mm})$; The G-mass of the egg in the shell $(\mathrm{g})$.

Color parameters were measured on the yolk surface of each egg sample using a Minolta Chroma Meter CR-400 colorimeter, with an $8 \mathrm{~mm}$ aperture on the measuring head and a standard CR-A33b measuring attachment (Konica Minolta Inc., Osaka, Japan). 
J. Perić and M. Drinić: Enriching table eggs with omega-3 fatty acids by using ground flaxseed or a combination of flax cake and flaxseed oil in the diet of laying hens

Table 1. Chemical composition of flaxseed, flax cake and flax oil

\begin{tabular}{|l|c|c|c|}
\hline Chemical Composition & Flaxseed & $\begin{array}{c}\text { Flax cake } \\
\text { (mechanically extracted oil })\end{array}$ & Flax oil \\
\hline Dry matter \% & 88.00 & 91.00 & - \\
\hline Crude protein \% & 22.00 & 31.50 & - \\
\hline Crude fat \% & 35.90 & 8.60 & - \\
\hline Crude fiber \% & 9.00 & 10.50 & - \\
\hline Lysine \% & 0.92 & 1.18 & - \\
\hline Methionine \% & 0.37 & 0.53 & 34.02 \\
\hline Cystine \% & 0.42 & 0.56 & 6.10 \\
\hline AME MJ/kg & 15.86 & 9.81 & 18.10 \\
\hline Palmitic fatty acid (C16:0) \% & - & - & 16.34 \\
\hline Oleic fatty acid (C18:1 n-9) \% & - & - & 51.86 \\
\hline Linoleic fatty acid (C18:2 n-6) \% & 5.39 & 1.28 & 4.01 \\
\hline Linolenic fatty acid (C18:3 n-3) \% & 16.80 & & - \\
\hline
\end{tabular}

- No data

Table 2. Composition of feed for the diet of laying hens

\begin{tabular}{|c|c|c|c|c|c|}
\hline & & Control group & $\begin{array}{c}\text { Flax cake } \\
+ \text { flax oil group }\end{array}$ & $\begin{array}{l}\text { Flax 5\% } \\
\text { group }\end{array}$ & $\begin{array}{l}\text { Flax } 10 \% \\
\text { group }\end{array}$ \\
\hline $\begin{array}{l}\text { Ordinal } \\
\text { No. }\end{array}$ & Raw material & $\begin{array}{l}\text { Proportion of the } \\
\text { mixture (\%) }\end{array}$ & $\begin{array}{l}\text { Proportion of } \\
\text { the mixture }(\%)\end{array}$ & $\begin{array}{l}\text { Proportion of the } \\
\text { mixture }(\%)\end{array}$ & $\begin{array}{l}\text { Proportion of } \\
\text { the mixture }(\%)\end{array}$ \\
\hline 01. & Maize & 57.95 & 53.89 & 56.25 & 54.45 \\
\hline 02. & Soy oil & 1.70 & - & 0.80 & - \\
\hline 03. & Lysine & - & 0.02 & - & - \\
\hline 04. & Methionine (99\%) & 0.15 & 0.14 & 0.15 & 0.15 \\
\hline 05. & Soybean meal (45\%) & 25.10 & 19.00 & 22.80 & 20.50 \\
\hline 06. & Sunflower meal (33\%) & 3.00 & 3.00 & 3.00 & 3.00 \\
\hline 07. & Flaxseed grounded & - & - & 5.00 & 10.00 \\
\hline 08. & Flax cake & - & 10.00 & - & - \\
\hline 09. & Flax oil & - & 2.00 & - & - \\
\hline 10. & Mono calcium phosphate & 1.38 & 1.25 & 1.30 & 1.20 \\
\hline 11. & Sodium bicarbonate & 0.27 & 0.25 & 0.25 & 0.25 \\
\hline 12. & Salt & 0.25 & 0.25 & 0.25 & 0.25 \\
\hline 13. & Limestone & 9.00 & 9.00 & 9.00 & 9.00 \\
\hline 14. & Premix & 1.00 & 1.00 & 1.00 & 1.00 \\
\hline 15. & Mycotoxin adsorbent & 0.20 & 0.20 & 0.20 & 0.20 \\
\hline \multicolumn{2}{|l|}{ Total } & 100 & 100 & 100 & 100 \\
\hline \multicolumn{6}{|c|}{ Chemical composition of the mixture (calculated) } \\
\hline 16. & Dry matter \% & 89.41 & 89.53 & 89.25 & 89.10 \\
\hline
\end{tabular}

Vitamin content and microelements per kg of feed: Vitamin A $11000 \mathrm{IJ}$; Vitamin $\mathrm{D}_{3} 2800 \mathrm{IJ}$; Vitamin E $30 \mathrm{mg}$; Vitamin $\mathrm{K}_{3} 3 \mathrm{mg}$; Vitamin B $_{1} 2 \mathrm{mg}$; Vitamin B $_{2} 5 \mathrm{mg}$; Vitamin B $_{6} 5 \mathrm{mg}$; Vitamin B $_{12} 0.025 \mathrm{mg}$; Vitamin C $20 \mathrm{mg}$; Biotin $0.1 \mathrm{mg}$; Choline chloride $450 \mathrm{mg}$; Folic acid $0.80 \mathrm{mg}$; Niacin $36 \mathrm{mg}$; Pantothenic acid $11 \mathrm{mg}$; Copper $6 \mathrm{mg}$; Iodine $1 \mathrm{mg}$; Iron $50 \mathrm{mg}$; Manganese $100 \mathrm{mg}$; Selenium $0.22 \mathrm{mg}$; Zinc $75 \mathrm{mg}$ 
J. Perić and M. Drinić: Enriching table eggs with omega-3 fatty acids by using ground flaxseed or a combination of flax cake and flaxseed oil in the diet of laying hens

Table 2. Composition of feed for the diet of laying hens (continued)

\begin{tabular}{|l|l|c|c|c|c|}
\hline \multicolumn{2}{|l|}{} & Control group & $\begin{array}{c}\text { Flax cake } \\
\text { +flax oil group }\end{array}$ & $\begin{array}{c}\text { Flax 5\% } \\
\text { group }\end{array}$ & $\begin{array}{c}\text { Flax 10\% } \\
\text { group }\end{array}$ \\
\hline 17. & ME (MEn) MJ/kg & 11.64 & 11.58 & 11.64 & 11.66 \\
\hline 18. & Crude proteins \% & 17.32 & 17.37 & 17.33 & 17.33 \\
\hline 19. & Total fat \% & 4.13 & 5.05 & 4.98 & 5.92 \\
\hline 20. & Raw ash \% & 12.93 & 12.35 & 12.68 & 12.41 \\
\hline 21. & Raw cellulose \% & 3.52 & 4.13 & 3.66 & 3.80 \\
\hline 22. & Lysine \% & 0.88 & 0.83 & 0.85 & 0.83 \\
\hline 23. & Methionine \% & 0.44 & 0.43 & 0.44 & 0.44 \\
\hline 24. & Methionine + Cystine \% & 0.73 & 0.73 & 0.73 & 0.74 \\
\hline
\end{tabular}

Vitamin content and microelements per kg of feed: Vitamin A $11000 \mathrm{IJ}$; Vitamin $\mathrm{D}_{3} 2800 \mathrm{IJ}$; Vitamin E $30 \mathrm{mg}$; Vitamin $\mathrm{K}_{3} 3 \mathrm{mg}$; Vitamin B $_{1} 2 \mathrm{mg}$; Vitamin B $_{2} 5 \mathrm{mg}$; Vitamin B $_{6} 5 \mathrm{mg}$; Vitamin $\mathrm{B}_{12} 0.025 \mathrm{mg}$; Vitamin C $20 \mathrm{mg}$; Biotin $0.1 \mathrm{mg}$; Choline chloride $450 \mathrm{mg}$; Folic acid $0.80 \mathrm{mg}$; Niacin $36 \mathrm{mg}$; Pantothenic acid $11 \mathrm{mg}$; Copper $6 \mathrm{mg}$; Iodine $1 \mathrm{mg}$; Iron $50 \mathrm{mg}$; Manganese $100 \mathrm{mg}$; Selenium $0.22 \mathrm{mg}$; Zinc $75 \mathrm{mg}$

Table 3. Total fat content and fatty acid composition of the feed used in the diet of laying hens (results of chemical analysis of mixtures used for laying hens)

\begin{tabular}{|c|c|c|c|c|}
\hline & \multicolumn{4}{|c|}{ Type of feed } \\
\hline & $\begin{array}{l}\text { Control } \\
\text { group }\end{array}$ & $\begin{array}{c}\text { Flax cake } \\
+ \text { flax oil group }\end{array}$ & $\begin{array}{l}\text { Flax 5\% } \\
\text { group }\end{array}$ & $\begin{array}{l}\text { Flax } 10 \% \\
\text { group }\end{array}$ \\
\hline$\%$ total fat & 4.08 & 5.74 & 5.65 & 6.37 \\
\hline \multicolumn{5}{|l|}{$\%$ fat acids } \\
\hline 16:0 Palmitic & 14.68 & 10.05 & 11.22 & 8.75 \\
\hline 16:1 Palmitoleic & 0.13 & 0.13 & 0.12 & 0.10 \\
\hline 17:0 Heptadecane & 0.11 & 0.08 & 0.08 & 0.07 \\
\hline 18:0 Stearic & 4.11 & 3.89 & 4.42 & 4.56 \\
\hline 18:1 n-9c Oleic & 29.19 & 28.38 & 26.11 & 23.63 \\
\hline 18:2 n-6c Linoleic & 45.65 & 25.14 & 32.11 & 23.38 \\
\hline 18:3 n-3 Linolenic & 5.16 & 31.57 & 24.98 & 38.80 \\
\hline 18:3 n-6 Linolenic & - & 0.08 & 0.07 & 0.10 \\
\hline 20:0 Arachidic & 0.52 & 0.35 & 0.38 & 0.31 \\
\hline 22:0 Behenic & 0.45 & 0.33 & 0.36 & 0.30 \\
\hline Saturated f.a. & 19.87 & 14.70 & 16.46 & 13.99 \\
\hline Monounsaturated f.a. & 29.32 & 28.51 & 26.23 & 23.72 \\
\hline Polyunsaturated f.a. & 50.81 & 56.79 & 57.31 & 62.29 \\
\hline Omega-6 f.a. & 45.65 & 25.22 & 32.33 & 23.49 \\
\hline Omega-3 f.a. & 5.16 & 31.57 & 24.98 & 38.80 \\
\hline Ratio $\omega-6: \omega-3$ f.a. & 8.85 & 0.80 & 1.29 & 0.61 \\
\hline
\end{tabular}

- not detected within detection limits $(<0.02 \%)$ 
Color characteristics are expressed in CIE $\mathrm{L}^{*} \mathrm{a}^{*}$ b* (CIE, 1976), which is based on three coordinates by which the color of the samples is defined: $\mathrm{L}^{*}($ color light), $a^{*}$ (contribution of red $\left(+a^{*}\right)$ or green $\left(-a^{*}\right)$ ) and $b^{*}$ (contribution of yellow $\left(+b^{*}\right)$ or blue $\left(-b^{*}\right)$ ).

Statistical analysis. Two-factor analysis of variance (IBM SPSS version 22 software package)

\section{Results}

The results presented in Table 2 and Table 3 show certain differences that existed in the total fat content in the mixtures for laying hens. These differences occurred because the total fat content in Table 2 was presented on the basis of the average content in nutrients, while in Table 3 it was presented on the basis of a chemical analysis of the content of fats and fatty acids in these feed mixtures for laying hens.

Table 4 shows the results of egg analyzes on Haugh units, total fat content, TBARS values, was used to process the obtained data. A significance level of $P \leq 0.05$ was used in all tests. In subsequent comparisons, Duncan's test was used. Results were expressed as average value \pm standard deviation. The paper dealt with the interaction effects between the effect of diet treatment (D) and the effect of experiment time $(\mathrm{T})$.

and the results of the measured instrumental color parameters at the end of weeks 5 and 10 from the start of the study.

The results of the two-factor analysis of variance obtained for Haugh units show that the treatments significantly affected the $5^{\text {th }}$ and $10^{\text {th }}$ weeks of the study. In terms of study time, statistically significant differences were noticed in all groups in the $5^{\text {th }}$ and $10^{\text {th }}$ week analyses.

The amount of fat was affected by the treatment in the $5^{\text {th }}$ and $10^{\text {th }}$ weeks of the study.

Table 4. Results of two - factor analysis of variance of egg quality parameters analyzed. A significance level of $\mathrm{P} \leq 0.05$ was used

\begin{tabular}{|c|c|c|c|c|c|c|c|c|}
\hline \multirow[b]{2}{*}{ Parameter } & \multirow[b]{2}{*}{$\begin{array}{l}\text { Week of } \\
\text { analyses }\end{array}$} & \multicolumn{4}{|c|}{ Treatment } & \multirow{2}{*}{$\begin{array}{l}\mathrm{D} \\
\mathrm{P}\end{array}$} & \multirow{2}{*}{$\begin{array}{l}\mathrm{T} \\
\mathrm{P}\end{array}$} & \multirow{2}{*}{$\begin{array}{c}\mathrm{D}^{* \mathrm{~T}} \\
\mathrm{P}\end{array}$} \\
\hline & & Control group & $\begin{array}{c}\text { Flaxseed cake } \\
+ \text { flaxseed oil group }\end{array}$ & $\begin{array}{l}\text { Flaxseed 5\% } \\
\text { group }\end{array}$ & $\begin{array}{l}\text { Flaxseed } 10 \% \\
\text { group }\end{array}$ & & & \\
\hline \multirow{2}{*}{$\begin{array}{l}\text { Haugh } \\
\text { units }\end{array}$} & 5. & $82.40 \pm 5.30^{\mathrm{bA}}$ & $85.44 \pm 5.14^{\mathrm{aA}}$ & $84.98 \pm 2.29^{\mathrm{bA}}$ & $85.54 \pm 5.05^{\mathrm{aA}}$ & \multirow{2}{*}{0.010} & \multirow{2}{*}{0.001} & \multirow{2}{*}{0.192} \\
\hline & 10. & $77.60 \pm 5.77^{\mathrm{bB}}$ & $83.87 \pm 3.74^{\mathrm{aB}}$ & $76.87 \pm 4.68^{\mathrm{bB}}$ & $83.58 \pm 5.01^{\mathrm{aB}}$ & & & \\
\hline \multirow{2}{*}{$\begin{array}{l}\text { Total fat } \\
\%\end{array}$} & 5. & $26.57 \pm 1.16^{\mathrm{a}}$ & $24.29 \pm 1.23^{\mathrm{bc}}$ & $23.26 \pm 1.69^{c}$ & $24.89 \pm 1.65^{\mathrm{b}}$ & \multirow{2}{*}{0.002} & \multirow{2}{*}{0419} & \multirow{2}{*}{0.034} \\
\hline & 10. & $25.36 \pm 1.73^{\mathrm{a}}$ & $23.15 \pm 1.32^{b}$ & $25.05 \pm 1.78^{\mathrm{ab}}$ & $24.12 \pm 2.17^{\mathrm{ab}}$ & & & \\
\hline \multirow{2}{*}{$\begin{array}{l}\text { TBARS } \\
\text { mg MDA/ } \\
\text { kg of yolk }\end{array}$} & 5. & $0.11 \pm 0.01 \mathrm{~d}^{\mathrm{A}}$ & $0.18 \pm 0.01^{\mathrm{aA}}$ & $0.15 \pm 0.01^{\mathrm{bA}}$ & $0.14 \pm 0.00^{c}$ & \multirow{2}{*}{0.000} & \multirow{2}{*}{0.000} & \multirow{2}{*}{0.000} \\
\hline & 10. & $0.06 \pm 0.01^{\mathrm{cB}}$ & $0.11 \pm 0.03^{\mathrm{bB}}$ & $0.07 \pm 0.01^{\mathrm{cB}}$ & $0.14 \pm 0.01^{\mathrm{a}}$ & & & \\
\hline \multirow{2}{*}{$\begin{array}{l}\text { Yolk color } \\
\text { L* }^{*}\end{array}$} & 5. & $56.94 \pm 1.55$ & $56.56 \pm 1.46$ & $56.54 \pm 1.31$ & $56.68 \pm 1.12$ & \multirow{2}{*}{0.004} & \multirow{2}{*}{0.294} & \multirow{2}{*}{0.003} \\
\hline & 10. & $56.93 \pm 1.32$ & $59.48 \pm 1.70$ & $55.73 \pm 1.72$ & $56.17 \pm 1.68$ & & & \\
\hline \multirow{2}{*}{$\begin{array}{l}\text { Yolk color } \\
\mathrm{a}^{*}\end{array}$} & 5. & $10.76 \pm 1.61$ & $10.59 \pm 1.06$ & $11.72 \pm 1.49$ & $10.52 \pm 1.46$ & \multirow{2}{*}{0.056} & \multirow{2}{*}{0.768} & \multirow{2}{*}{0.293} \\
\hline & 10. & $11.69 \pm 0.74$ & $9.98 \pm 1.57$ & $11.29 \pm 1.00$ & $11.01 \pm 1.25$ & & & \\
\hline \multirow{2}{*}{$\begin{array}{l}\text { Yolk color } \\
\mathrm{b}^{*}\end{array}$} & 5. & $40.19 \pm 2.37$ & $38.95 \pm 3.32^{\mathrm{B}}$ & $38.47 \pm 2.26$ & $37.51 \pm 2.13$ & \multirow{2}{*}{0.012} & \multirow{2}{*}{0.073} & \multirow{2}{*}{0.032} \\
\hline & 10. & $38.86 \pm 2.58^{\mathrm{b}}$ & $43.07 \pm 3.21^{\mathrm{aA}}$ & $39.33 \pm 1.66^{b}$ & $38.48 \pm 2.27^{\mathrm{b}}$ & & & \\
\hline
\end{tabular}

Lowercase letters are used to indicate significant differences between the mean values of individual treatments. Capital letters are used to indicate significant differences between individual weeks of analysis within individual treatments. Two averages denoted by the same lowercase or uppercase letter do not differ significantly. 
J. Perić and M. Drinić: Enriching table eggs with omega-3 fatty acids by using ground flaxseed or a combination of flax cake and flaxseed oil in the diet of laying hens

Table 5. The results of a two - factor analysis of the variance of the fatty acid composition of egg yolks. A significance level of $\mathrm{P} \leq 0.05$ was used

\begin{tabular}{|c|c|c|c|c|c|c|c|c|}
\hline \multirow[b]{2}{*}{ Fatty acids } & \multirow[b]{2}{*}{$\begin{array}{l}\text { Week of } \\
\text { analyses }\end{array}$} & \multicolumn{4}{|c|}{ Treatment } & \multirow{2}{*}{$\begin{array}{l}\mathrm{D} \\
\mathrm{P} \\
\end{array}$} & \multirow{2}{*}{$\begin{array}{l}\mathrm{T} \\
\mathrm{P}\end{array}$} & \multirow{2}{*}{$\begin{array}{c}\mathrm{D} * \mathrm{~T} \\
\mathrm{P}\end{array}$} \\
\hline & & Control group & $\begin{array}{l}\text { Flaxseed cake } \\
+ \text { flaxseed oil } \\
\text { group }\end{array}$ & $\begin{array}{l}\text { Flaxseed } \\
5 \% \text { group }\end{array}$ & $\begin{array}{l}\text { Flaxseed } \\
10 \% \text { group }\end{array}$ & & & \\
\hline \multirow{2}{*}{ C18:2 c Linoleic } & 5. & $18.54 \pm 1.03^{\mathrm{aB}}$ & $15.39 \pm 1.22^{\mathrm{cB}}$ & $16.98 \pm 1.67^{\mathrm{bB}}$ & $16.03 \pm 1.28^{\mathrm{cB}}$ & \multirow{2}{*}{0.000} & \multirow{2}{*}{0.000} & \multirow{2}{*}{0.155} \\
\hline & 10. & $21.52 \pm 1.61^{\mathrm{aA}}$ & $16.97 \pm 1.14^{\mathrm{cA}}$ & $18.55 \pm 1.43^{\mathrm{bA}}$ & $16.72 \pm 1.75^{\mathrm{cA}}$ & & & \\
\hline \multirow{2}{*}{$\begin{array}{l}\text { C18:3 n-3 } \\
\text { Linolenic }\end{array}$} & 5. & $0.47 \pm 0.04 \mathrm{~d}^{\mathrm{B}}$ & $7.60 \pm 0.87^{\mathrm{aB}}$ & $3.05 \pm 0.47^{\mathrm{cB}}$ & $5.86 \pm 0.66^{\mathrm{bB}}$ & \multirow{2}{*}{0.000} & \multirow{2}{*}{0.003} & \multirow{2}{*}{0.098} \\
\hline & 10. & $0.72 \pm 0.08 \mathrm{~d}^{\mathrm{A}}$ & $8.03 \pm 1.19^{\mathrm{aA}}$ & $3.27 \pm 0.45^{\mathrm{cA}}$ & $7.20 \pm 1.01^{\mathrm{bA}}$ & & & \\
\hline \multirow{2}{*}{$\begin{array}{l}\mathrm{C} 20: 4 \mathrm{n}-6 \\
\text { Arachidonic }\end{array}$} & 5. & $3.72 \pm 0.74^{\mathrm{aA}}$ & $1.75 \pm 0.21^{\mathrm{cA}}$ & $2.55 \pm 0.66^{\mathrm{bA}}$ & $3.21 \pm 1.06^{\mathrm{abA}}$ & \multirow{2}{*}{0.000} & \multirow{2}{*}{0.000} & \multirow{2}{*}{0.001} \\
\hline & 10. & $2.34 \pm 0.22^{\mathrm{aB}}$ & $1.02 \pm 0.12^{\mathrm{cB}}$ & $1.63 \pm 0.38^{\mathrm{bB}}$ & $0.96 \pm 0.08^{\mathrm{cB}}$ & & & \\
\hline \multirow{2}{*}{$\begin{array}{l}\mathrm{C} 20: 5 \mathrm{n}-3 \\
\text { Eicosapentaenoic }\end{array}$} & 5. & $0.00 \pm 0.00^{c}$ & $0.19 \pm 0.08^{\mathrm{aA}}$ & $0.02^{\mathrm{a}} \pm 0.06^{\mathrm{cA}}$ & $0.14 \pm 0.06^{\mathrm{bA}}$ & \multirow{2}{*}{0.000} & \multirow{2}{*}{0.003} & \multirow{2}{*}{0.170} \\
\hline & 10. & $0.00 \pm 0.00^{c}$ & $0.12 \pm 0.05^{\mathrm{aB}}$ & $0.00^{\mathrm{a}} \pm 0.00^{\mathrm{cB}}$ & $0.08 \pm 0.07^{\mathrm{bB}}$ & & & \\
\hline \multirow{2}{*}{$\begin{array}{l}\text { C22:6 n-3 } \\
\text { Docosahexaenoic }\end{array}$} & 5. & $1.84 \pm 0.09^{\mathrm{c}}$ & $3.90 \pm 0.46^{\mathrm{ab}}$ & $3.77 \pm 0.41^{\mathrm{bA}}$ & $4.30 \pm 0.51^{\mathrm{a}}$ & \multirow{2}{*}{0.000} & \multirow{2}{*}{0.000} & \multirow{2}{*}{0.018} \\
\hline & 10. & $1.87 \pm 0.25^{\mathrm{c}}$ & $3.48 \pm 0.44^{\mathrm{a}}$ & $2.89 \pm 0.42^{\mathrm{bB}}$ & $3.68 \pm 0.50^{\mathrm{a}}$ & & & \\
\hline \multirow{2}{*}{$\begin{array}{l}\text { Saturated fatty } \\
\text { acids }\end{array}$} & 5. & $29.28 \pm 2.58^{\mathrm{aA}}$ & $26.63 \pm 0.67^{\mathrm{cA}}$ & $28.42 \pm 1.10^{\mathrm{bA}}$ & $26.86 \pm 0.70^{\mathrm{cA}}$ & \multirow{2}{*}{0.000} & \multirow{2}{*}{0.001} & \multirow{2}{*}{0.770} \\
\hline & 10. & $28.27 \pm 1.24^{\mathrm{aB}}$ & $25.03 \pm 0.90^{\mathrm{cB}}$ & $27.33 \pm 0.81^{\mathrm{bB}}$ & $26.19 \pm 0.91^{\mathrm{cB}}$ & & & \\
\hline \multirow{2}{*}{$\begin{array}{l}\text { Monounsaturated } \\
\text { fatty acids }\end{array}$} & 5. & $45.05 \pm 1.11^{\mathrm{B}}$ & $44.53 \pm 1.05^{\mathrm{B}}$ & $45.01 \pm 1.79^{\mathrm{B}}$ & $43.38 \pm 1.94^{\mathrm{B}}$ & \multirow{2}{*}{0.093} & \multirow{2}{*}{0.028} & \multirow{2}{*}{0.509} \\
\hline & 10. & $45.09 \pm 1.39^{\mathrm{A}}$ & $45.18 \pm 1.44^{\mathrm{A}}$ & $46.17 \pm 0.93^{\mathrm{A}}$ & $45.01 \pm 2.19^{\mathrm{A}}$ & & & \\
\hline \multirow{2}{*}{$\begin{array}{l}\text { Polyunsaturated } \\
\text { fatty acids }\end{array}$} & 5. & $24.80 \pm 1.31^{\mathrm{b}}$ & $28.83 \pm 1.25^{\mathrm{a}}$ & $26.58 \pm 2.51^{\mathrm{b}}$ & $29.75 \pm 2.32^{\mathrm{a}}$ & \multirow{2}{*}{0.000} & & \\
\hline & 10. & $26.64 \pm 1.75^{\mathrm{b}}$ & $29.79 \pm 1.92^{\mathrm{a}}$ & $26.50 \pm 1.37^{\mathrm{b}}$ & $28.81 \pm 2.45^{\mathrm{a}}$ & & & 0.20 \\
\hline
\end{tabular}

Lowercase letters are used to indicate significant differences between the mean values of individual treatments. Capital letters are used to indicate significant differences between individual weeks of analysis within individual treatments. Two averages denoted by the same lowercase or uppercase letter do not differ significantly.

However, unlike the treatments, time did not significantly affect this parameter, so there were no statistically significant differences within the same groups in the $5^{\text {th }}$ and $10^{\text {th }}$ week analyses.

The effect of treatment on the registered TBARS values was significant in both the $5^{\text {th }}$ and $10^{\text {th }}$ weeks of the study. In terms of study time, the $10 \%$ flax treatment did not show a statistically significant difference between the $5^{\text {th }}$ and $10^{\text {th }}$ weeks, while significant differences were noticed in the other three groups.

The results presented in Table 4 show that the light color $\left(\mathrm{L}^{*}\right)$ of the yolk was not significantly affected by the treatment at the $5^{\text {th }}$ and $10^{\text {th }}$ weeks of the study. There were no statistically significant differences within the same groups regarding the time of the study.
The values obtained for the presence of red color $\left(a^{*}\right)$ show that neither the treatment nor the time significantly affected this parameter.

The presence of yellow color ( $\left.b^{*}\right)$ indicated that there was no significant effect of treatment in the $5^{\text {th }}$ week of the study, whereas in the $10^{\text {th }}$ week the treatment with flax cake + flax oil had a significantly higher value for yellow color than the other groups. Also, the study time only significantly affected the treatment of flax cake + flax oil, while in the other groups there was no statistically significant difference in the analyses in the $5^{\text {th }}$ and $10^{\text {th }}$ weeks of the study.

Table 5 presents the results of the fatty acid composition of egg yolks at the end of the $5^{\text {th }}$ and $10^{\text {th }}$ weeks of the study. The results are presented as the average $\%$ of fatty acids in the separated fatty phase of the yolk. 
The results presented in Table 5 show that the treatment influenced the content of linoleic acid in the $5^{\text {th }}$ and $10^{\text {th }}$ weeks, resulting in a significant difference in its content between the groups, so that the amount of this fatty acid in the control group was significantly higher than in the treatment groups. In terms of time, statistically significant differences were noticed for all groups in the $5^{\text {th }}$ and $10^{\text {th }}$ week analyses.

From the results presented in Table 5 it can be seen that the average amount of ALA in the egg yolk was significantly $(\mathrm{P}<0.05)$ influenced by the nutritional treatments in both the $5^{\text {th }}$ and $10^{\text {th }}$ weeks of the experiment. Also, from the results it may be seen that the average amount of ALA in the egg yolks obtained from the laying hens treated with the flax cake + flax oil treatment was significantly $(\mathrm{P}<0.05)$ highest. Egg yolks obtained from laying hens treated with $10 \%$ flax had significantly $(\mathrm{P}<0.05)$ lower average amounts of ALA compared to the yolks of laying hens treated with the flax cake + flax oil treatment, but also a significantly higher amount of ALA compared to the yolks obtained from laying hens treated with 5\% flax. The laying hens in the control group had $(\mathrm{P}<0.05)$ the significantly lowest average amount of ALA in their egg yolks. Also, in terms of analysis time in relation to the egg yolks of all the groups of laying hens, statistically significantly higher average amounts of ALA were recorded at 10 weeks compared to the average amounts at 5 weeks of the experiment.

The arachidonic fatty acid level was affected at both the $5^{\text {th }}$ and $10^{\text {th }}$ weeks of treatment, as well as in terms of the time effect, and this also affected all groups with a significant decrease in the level at 10 weeks compared to the level at 5 weeks of the study.

The EPA level was affected in both the $5^{\text {th }}$ and $10^{\text {th }}$ weeks of the study. The influence of time was only not significant in the control group, while other treatment groups reported significant differences in the analysis at the $5^{\text {th }}$ and $10^{\text {th }}$ weeks.

From the results presented for the level of DHA, it can be seen that treatment affected it considerably at the $5^{\text {th }}$ and $10^{\text {th }}$ weeks, while in terms of time, only in the treatment with 5\% flax was a statistically significant difference registered in the amounts at the $5^{\text {th }}$ and $10^{\text {th }}$ weeks.

Analysis of saturated fatty acids show the significant influence of treatment at the $5^{\text {th }}$ and $10^{\text {th }}$ weeks. In addition to the treatment, time also significantly affected all groups, with significant differences between analyses in the $5^{\text {th }}$ and $10^{\text {th }}$ weeks of the study.

From the results presented in Table 5 it can be seen that amount of monounsaturated fatty acids (MUFA) was not significantly affected by the treatment, while the time effect during the study was significant, so all groups had significantly higher values at the $10^{\text {th }}$ week than those at the $5^{\text {th }}$ week of the study.

The amount of PUFA was affected in both the $5^{\text {th }}$ and $10^{\text {th }}$ weeks, which showed that the quantities are statistically significantly higher after treatment with flax cake + flax oil and $10 \%$ flax compared to the quantities after the $5 \%$ flax treatment and the control group. However, time effect was not significant within the same group between the $5^{\text {th }}$ and $10^{\text {th }}$ weeks.

\section{Discussion}

The results presented in this paper for Haugh units showed significantly higher values of enriched treatments flax cake + flax oil and $10 \%$ flax compared to $5 \%$ flax treatment and the control group. Similar results were found in studies by AZIZA et al. (2013), while RAKITA et al. (2016) found no significant differences between the groups in their study.

The results presented show that the average amount of fat in egg yolks registered in the analysis at 5 weeks of the experiment was statistically significantly $(\mathrm{P}<0.05)$ highest in the control group. In the analysis at 10 weeks of research, the average amount of fat registered in egg yolks from laying hens in the control group was significantly $(\mathrm{P}<0.05)$ higher in relation to the laying hens with enriched treatment of flax cake + flax oil, while in relation to laying hens with enriched treatments 5\% flax and $10 \%$ flax, it did not differ significantly. MRIDULA et al. (2012) in their study did not find a statistically significant difference in the amount of fat in the eggs 
of laying hens fed with $0,2.5,5.0,7.5$ and $10 \%$ of ground flaxseed in their feed. However, AYERZA and COATES (2001) stated that the amount of lipid in the yolks was the lowest in the groups with three feeds with the highest amount of $\alpha$-linoleic acid in their composition in comparison to eggs obtained from the treatment with a slightly lower amount of $\alpha$-linoleic acid, and the control group with the lowest amount of this fatty acid.

The registered TBARS values showed the significant effect of PUFA enriched treatments in relation to the control group, with the exception of the $5 \%$ flax treatment at 10 weeks' analysis, where there was no significant difference to the control group. The TBARS value was a measurement of lipid peroxidation, and the higher the concentration of unsaturated fatty acids in egg yolk as a result of adding a PUFA n-3 source, the higher the sensitivity was to lipid peroxidation, which was mainly shown in this paper too. Similar results suggesting an increase in TBARS values in egg yolks obtained from a diet supplemented with PUFA omega-3enriched feeds were also reported by ZOTTE et al. (2015) and MATTIOLI et al. (2016).

The results obtained for color light ( $\left.\mathrm{L}^{*}\right)$ indicated that there was no statistically significant effect of PUFA-enriched treatments on its value in relation to the control group.

The level of red color $\left(a^{*}\right)$ indicated that there were no statistically significant differences between the groups in both analyses. The results obtained for the level of yellow color $\left(b^{*}\right)$ showed that there was no significant difference between the 5 and 10 weeks' results, but only with flax cake + flax oil treatment was there a significantly higher level than in the other groups. Yolk color is a very important trait of egg quality that affects consumer acceptance (LACA et al., 2009). CACHALDORA et al. (2006) reported a decrease in yolk color when PUFA omega-3 sources were added to feed. ZOTTE et al. (2015) reported that the variation in yolk color during the experimental diet was not significant in terms of light $\left(\mathrm{L}^{*}\right)$ and yellow $\left(\mathrm{b}^{*}\right)$ values, whereas a nonlinear trend was found for redness $\left(\mathrm{a}^{*}\right)$ that did not show any biological association with diet treatment.
The level of linoleic acid in both analyses showed the statistically significant highest amount in the control group compared to the observed treatments. Flax cake + flax oil and 10\% flax treatments had significantly lower values in both analyses compared to the $5 \%$ flax treatment. YASSEIN et al. (2015) stated in their paper that they found no significant difference in the amount of linoleic acid between the groups with 0,5 and $10 \%$ of flaxseed in their feed, while the group with $15 \%$ of flaxseed in the feed had a significantly lower amount of this fatty acid in their eggs. CHERIAN and QUEZADA (2016) stated that there was no significant difference in the content of linoleic acid between the control group and the groups with $10 \%$ camelina seed or $10 \%$ flax seed added.

Theobserved amount of ALA showed a significant increase in the treatment groups compared to the control group. In both analyses, the flax cake + flax oil treatment had a statistically significantly higher level than the other groups, although the analysis of fodder used in the diet of the laying hens showed a lower amount of linoleic acid in the feed in the flax cake + flax oil treatment compared to the treatment with $10 \%$ flax. The observation in this paper may be partly explained by the fact that linoleic fatty acid from feed enriched with flaxseed cake and flaxseed oil has better digestibility, and thus was better converted to linoleic fatty acid in egg yolks compared to linoleic acid from feed enriched with 10\% flax. MRIDULA et al. (2012) reported higher ALA depositions in birds' eggs with increasing age. YASSEIN et al. (2015) stated that an increase in flaxseed in feed by up to $15 \%$ led to an increase in linoleic acid in the yolk lipids in relation to the control group. These results were in agreement with the results of CHERIAN and QUEZADA (2016).

The registered amounts of arachidonic fatty acid in both analyses showed a decrease in the observed treatment groups, which was especially significant in the analysis at the end of week 10, where the control group had the largest amount compared to the other treatments. PETROVIĆ et al. (2012) reported that the amount of arachidonic fatty acid showed a significant $(\mathrm{P}<0.0001)$ decrease in correlation to the amount of flaxseed oil added to feed. Also, SHAFEY et al. (2015) pointed out that 
adding flaxseed meal (5 and 10\%) to the feed of laying hens led to a significant $(\mathrm{P}<0.01)$ decrease in the amount of arachidonic acid in the eggs of the enriched treatment groups compared to the control group. Other authors made similar observations in their work (IMRAN et al., 2015; ZOTTE et al., 2015).

In the analyses at the end of weeks 5 and 10, EPA was not registered in the control group, while in the treatment with 5\% flax it was not registered in the analysis at 10 weeks. The flax cake + flax oil treatment group had a statistically significantly higher amount of EPA in both analyses compared to the $10 \%$ flax treatment group. EHR et al. (2017) stated in their paper that the concentration of EPA and DHA in the yolk was not influenced by PUFA source (flaxseed oil or ground flaxseed), but increasing the amount of oil in feed from any source significantly increased the amount of EPA and DHA in the yolk. The results obtained are in agreement with those of other authors (LEESON and CASTON, 2004; MATTIOLI et al., 2016).

The registered amounts of DHA indicated that the control group had a statistically significantly lower amount compared to the treatment groups in both analyses. EBEID et al. (2008) ) reported that a diet for laying hens containing fish oil resulted in a proportional increase in $n-3$ PUFA $(\mathrm{P} \leq 0.05)$ in egg yolk lipids. WESTBROOK and CHERIAN (2019) reported that the addition of enzymes to the diet of laying hens with flaxseed $(10 \%)$ had no effect on DHA, total long-chain fatty acids (> 20-C FA), or on the omega-6:omega-3 fatty acid ratio. The results obtained in this paper are in agreement with the results of ZOTTE et al. (2015).

The registered amounts of saturated fatty acids (SFA) showed that the control group had statistically significantly higher values compared to the $5 \%$ flax treatment at both analyses, and there were also significantly higher values compared to the treatments of flax cake + flax oil and $10 \%$ flax. The amounts of SFA registered within the same groups were significantly lower at the 10 -week analysis compared to the 5-week analysis. YASSEIN et al. (2015) reported a significant decrease in saturated fatty acids in PUFA-enriched treatments compared to the control group. Similar observations were presented in MATTIOLI et al. (2016).

The amounts of MUFA recorded in the analyzes at the end of the $5^{\text {th }}$ and $10^{\text {th }}$ weeks showed no significant differences between the control group and the other treatments. However, within the same groups, values recorded at 10 weeks were statistically significantly higher than values recorded at 5 weeks of the study. LEESON and CASTON (2004) reported that there was no significant difference in monounsaturated fatty acid content between the control group and treatments containing $10 \%$ flaxseed or $10 \%$ flaxseed that was either 50 or $90 \%$ dehulled. However, SHAFEY et al. (2015) pointed out that the groups fed with 5 and $10 \%$ flaxseed meal had significantly lower amounts of monounsaturated fatty acids compared to the control group.

The PUFA content registered at the 5 and 10 week analyses showed a significantly lower amount in the control group and treatment 5\% flax compared to the other two treatments, while there were no significant differences within the same groups. Previous results showed that highest amount of polyunsaturated fatty acids was recorded in treatments with $15 \%$ flaxseed added, compared to treatments with 5 and $10 \%$ flaxseed added, and the control group (SULTAN et al., 2015). The amount of PUFA in eggs listed in Table 5 showed a significant increase in accordance with the amount of PUFA added through feed, which is also supported by other studies (LEESON and CASTON, 2004; ZOTTE et al., 2015).

\section{Conclusion}

The results presented in this paper show that the adding flaxseed (natural, grounded) at a concentration of 5 and $10 \%$, as well as adding flaxseed cake at a concentration of $10 \%$ together with flaxseed oil at a concentration of $2 \%$ led to a statistically significant increase in ALA and DHA in eggs compared to the control group. A significant decrease in the amount of saturated fatty acids in PUFA-enriched treatments was observed in the trial, compared with the control group. Also, the results of this experiment showed that there was no statistically significant difference between the 
control group and PUFA enriched treatments in terms of the amount of monounsaturated fatty acids. There was a statistically significantly higher amount of PUFA in this trial in the flax cake + flax oil and $10 \%$ flax treatment groups, compared to the $5 \%$ flax treatment group and the control group, between which there was no significant difference.

\section{References}

AYERZA, R., W. COATES (2001): Omega-3 enriched eggs: The influence of dietary $\alpha \alpha$-linolenic fatty acid source on egg production and composition 1. Can. J. Anim. Sci. 81, 355-362.

DOI: $10.4141 / \mathrm{A} 00-094$

AZIZA, A. E., A.K. PANDA, N. QUEZADA, G. CHERIAN (2013): Nutrient digestibility, egg quality, and fatty acid composition of brown laying hens fed camelina or flaxseed meal. J. Appl. Poult. Res. 22, 832-841.

DOI: 10.3382/japr.2013-00735

BOStOGLOU, N. A., D. J. FLETOURIS, G. E. PAPAGEORGIU, V. N. VASSILOPOULOS, A. J. MANTIS, A.G. TRAKATELLIS (1994): Rapid sensitive and specific thiobarbituric acid method for measuring lipid peroxidation in animal tissue, food and feedstuff samples. J. Agric. Food Chem. 42, 1931-1937.

CACHALDORA, P., P. GARCÍA-REBOLLAR, C. ALVAREZ, J. C. DE BLAS, J. MÉNDEZ (2006): Effect of type and level of fish oil supplementation on yolk fat composition and n-3 fatty acids retention efficiency in laying hens. Br. Poult. Sci. 47,43-49.

DOI: $10.1080 / 00071660500475541$

ČENGIĆ-DŽOMBA, S., S. MURATOVIĆ, E. DŽOMBA (2014): Effect of feeding regime by designed mixture on broilers' breast muscle fatty acids profile. Krmiva 56, 8188.

CHERIAN, G., N. QUEZADA (2016): Egg quality, fatty acid composition and immunoglobulin $\mathrm{Y}$ content in eggs from laying hens fed full fat camelina or flax seed. J. Anim. Sci. Biotechnol. 7, 374-361.

DOI: $10.1186 / \mathrm{s} 40104-016-0075-\mathrm{y}$

COOREY, R., A. TJOE, V. JAYASENA (2014): Gelling properties of chia seed and flour. J. Food Sci. 79, 859-66. DOI: $10.1111 / 1750-3841.12444$

EBEID, T., Y. EID, A. SALEH, H. ABD EL-HAMID (2008): Ovarian follicular development, lipid peroxidation, antioxidative status and immune response in laying hens fed fish oil supplemented diets to produce omega-3 enriched eggs. Animal 2, 84-91.

DOI: $10.1017 / \mathrm{S} 1751731107000882$

EHR, I. J., M. E. PERSIA, E. A. BOBECK (2017): Comparative omega-3 fatty acid enrichment of egg yolks from first-cycle laying hens fed flaxseed oil or ground flaxseed. Poult. Sci. 6, 1791-1799.

DOI: $10.3382 /$ ps/pew462

FOLCH, J., M. LEES, G. H. S. STANLEY (1957): A simple method for the isolation and purification of total lipids from animal tissues. J. Biol. Chem. 226, 497-509.

IMRAN, M., A. F. MUHAMMAD, M. NADEEM, N. AHMAD, K. M. KARMAN, Z. MUSHTAQ, S. HUSSAIN (2015): Production of Bio-omega-3 eggs through the supplementation of extruded flaxseed meal in hen diet. Lipids Health Dis. 14, 126.

JUTURU, V. (2008): Omega-3 fatty acids and the cardiometabolic syndrome. J. Cardiometab. Syndr. 3, 24453.

DOI: $10.1111 /$ j.1559-4572.2008.00015.x

LACA, A., B. PAREDES, M. DÍAZ (2009): Quality characteristics of n-3 polyunsaturated fatty acidenriched eggs. J. Anim. Feed Sci. 18, 101-112.

LEESON, S., L. J. CASTON (2004): Feeding value of dehulled flaxseed. Can. J. Anim. Sci. 84, 545-547.

MANDIĆ, A. (2007): Antioxidant properties of extracts of seeds from varieties of white grapes. PhD Thesis, Faculty of Technology, Novi Sad, Serbia.

MATTIOLI, S., S. RUGGERI, B. SEBASTIANI, G. BRECCHIA, A. DAL BOSCO, A. CARTONI MANCINELLI, C. CASTELLINI (2016): Performance and egg quality of laying hens fed flaxseed: highlights on n-3 fatty acids, cholesterol, lignans and isoflavones. Animal 11, 705-712.

DOI: $10.1017 / \mathrm{S} 175173111600207 \mathrm{X}$

MRIDULA, D., D. KAUR, S. S. NAGRA, P. BARNWAL, S. GURUMAYUM, K. K. SINGH (2012): Effect of dietary flaxseed supplementation on egg production and quality in laying hens. Indian J. Poult. Sci. 47, 40-47.

PETROVIĆ, M., M. GAČIĆ, V. KARAČIĆ, Ž. GOTTSTEIN, H. MAZIJA, H. MEDIĆ (2012): Enrichment of eggs in n-3 polyunsaturated fatty acids by feeding hens with different amount of linseed oil in diet. Food Chem. 135, 1563-1568. DOI: 10.1016/j.foodchem.2012.06.020

POŁAWSKA, E., J. O. HORBAŃCZUK, M. PIERZCHAŁA, N. STRZAŁKOWSKA, A. JÓŹWIK, A. WÓJCIK, J. POMIANOWSKI, K. GUTKOWSKA, A. WIERZBICKA, L.C. HOFFMAN (2013): Effect of dietary linseed and rapeseed supplementation on fatty acid profiles in the ostrich. Anim. Sci. Pap. Rep. 31, 239-248.

RAKITA, S., N. SPASEVSKI, D. ČOLOVIĆ, S. POPOVIĆ, P. IKONIĆ, R. ČOLOVIĆ, J. LEVIĆ (2016): The influence of laying hens' diet enriched with omega-3 fatty acids, paprika and marigold on physical properties of eggs. J. Proc. En. Agric. 20 (2), 58-62.

SALEH, A. A. (2013): Effects of fish oils on the production performances and polyunsaturated fatty acids and 
J. Perić and M. Drinić: Enriching table eggs with omega-3 fatty acids by using ground flaxseed or a combination of flax cake and flaxseed oil in the diet of laying hens

cholesterol levels of yolk in hens. Emir. J. of Food and Agric. 25 (8), 605-612.

DOI: $10.9755 /$ ejfa.v25i8.14005

SALEH, A. A., T. EBEID, Y. EID (2013): The effect of dietary linseed oil and organic selenium on growth performance and muscle fatty acids in rabbit. Pak. Vet. J. 33, 450-454.

ŠEFER, D., A. ANDONOV, S. ŠOBAJIĆ, R. MARKOVIĆ, S. RADULOVIĆ, D. JAKIĆ-DIMIĆ, B. PETRUJKIĆ (2011): Effects of feeding laying hens diets supplemented with omega 3 fatty acids on the egg fatty acid profile. Biotech. Anim. Husb. 27, 679-686.

DOI: 10.2298/BAH1103679S

SHAFEY, T. M., H. A. AL-BATSHAN, A. M. S. FARHAN (2015): The effect of dietary flaxseed meal on liver and egg yolk fatty acid profiles, immune response and antioxidant status of laying hens. Ital. J. Anim. Sci. 14, 428-435.

DOI: $10.4081 /$ ijas.2015.3939

SULTAN, A., H. OBAID, S. KHAN, I. REHMAN, M. K. SHAH, R. U. KHAN (2015): Nutritional effect of flaxseeds on cholesterol profile and fatty acids composition in egg yolk. Cer. Chem. 92,50-53.

DOI: 10.1094/CCHEM-05-14-0114-IA

WESTBROOK, L. A., G. CHERIAN (2019): Egg quality, fattyacid composition and gastrointestinal morphology of layer hens fed whole flaxseed with enzyme supplementation. Br. Poult. Sci. 60, 146-153.

DOI: $10.1080 / 00071668.2018 .1556783$

YASSEIN, S. A., G. M. EL-MALLAH, M. A. SAWSAN, A. A. EL-GHAMRY, M. M. ABDEL-FATTAH, D.M. ELHARRIRY (2015): Response of laying hens to dietary flaxseed levels on performance, egg quality criteria, fatty acid composition of egg and some blood parameters. Int. J. Res. Stud. Biosci. 3, 27-34.

ZOTTE, A. D., I. ANDRighetTo, V. GiACCONE, G. MARCHESINI (2015): Dietary enrichment of n-3 PUFA for laying hens: effect of different sources on production, composition and quality of eggs. Anim. Sci. Pap. and Rep. 33, 411-424.

Received: 26 December 2019

Accepted: 10 September 2020

PERIĆ, J., M. DRINIĆ: Uporaba mljevenih lanenih sjemenki ili kombinacije lanene pogače i lanenog ulja u prehrani nesilica za proizvodnju konzumnih jaja obogaćenih omega-3 masnim kiselinama. Vet. arhiv 91, 399409, 2021.

\section{SAŽETAK}

Cilj ovog rada bio je istražiti potencijal prehrane nesilica mljevenim lanenim sjemenkama i kombinacijom lanene pogače i lanenog ulja u proizvodnji jaja obogaćenih omega-3 masnim kiselinama. Istraživanje je provedeno na 192 nesilice podijeljene u 4 skupine: kontrolnu skupinu, skupinu hranjenu lanenom pogačom (10 \%) i lanenim uljem (2 \%), skupinu hranjenu s $5 \%$ mljevenih lanenih sjemenki i skupinu hranjenu s $10 \%$ mljevenih lanenih sjemenki. Svaka je skupina imala 8 nastambi s kavezima u kojima je bilo po 6 nesilica, ukupno 48 nesilica po skupini. Vrijednosti Haugh-ovih jedinica, sadržaj masti, vrijednosti reaktivne tvari tiobarbiturične kiseline (TBARS), pokazatelji boje žumanca i sadržaj masti žumanca izmjereni su na kraju 5. i 10. tjedna istraživanja. Rezultati su pokazali da je dijetna prehrana obogaćena omega-3 masnim kiselinama utjecala na ukupnu količinu masnoća u žumancu i TBARS test. Također, prehrana obogaćena omega-3 masnim kiselinama utjecala je na prosječnu količinu alfa-linoleične (ALA) i dokozaheksaenske (DHA) masne kiseline u žumancu. Nesilice koje su bile hranjene mješavinom obogaćenom s $5 \%$ i $10 \%$ mljevenih lanenih sjemenki, kao i $10 \%$ lanene pogače i $2 \%$ lanenog ulja, imale su znakovito veću $(\mathrm{P}<0,05)$ količinu ALA-e i DHA-a u žumancu u usporedbi s nesilicama u kontrolnoj skupini.

Ključne riječi: nesilice; prehrana; lanene sjemenke; lanena pogača; laneno ulje; obogaćena jaja 
